\title{
Reproduction of Oligosarcus hepsetus (Cuvier, 1829) (Characiforms) in the Serra do Mar State Park, São Paulo, Brazil
}

\author{
Gomiero, LM.*, Garuana, L. and Braga, FMS. \\ Departamento de Zoologia, Instituto de Biociências, Universidade Estadual Paulista - UNESP, \\ Av. 24-A, 1515, CP 199, CEP 13506-900, Rio Claro, SP, Brazil \\ *e-mail: leanmg@rc.unesp.br \\ Received April 28, 2006 - Accepted December 12, 2006 - Distributed February 29, 2006
}

(With 5 figures)

\begin{abstract}
The purpose of this study was to characterize the reproduction of Oligosarcus hepsetus in the Grande river (Santa Virginia Unit - Serra do Mar State Park) based on the reproductive period, length of first gonadal maturation for both sexes, sexual proportion, oocyte development, type of spawn and fecundity. The Grande river was sampled monthly from January through December 2004. The numerical frequency of the stages of maturity and the volumetric method were utilized to determine the reproductive period and fecundity, respectively. The reproduction of Oligosarcus hepsetus was characterized by a long period, relatively low fecundity, precocious length of first gonadal maturation and parceled spawning.
\end{abstract}

Keywords: Oligosarcus hepsetus, reproduction, Grande river, neotropical fishes.

\section{Reprodução de Oligosarcus hepsetus (Characiformes) no Parque Estadual da Serra do Mar, São Paulo, Brasil}

\begin{abstract}
Resumo
O objetivo foi caracterizar a reprodução de Oligosarcus hepsetus no rio Grande (Núcleo Santa Virgínia - Parque Estadual da Serra do Mar). Foram abordados o período reprodutivo, os comprimentos de primeira maturação gonadal para ambos os sexos, a proporção sexual, o desenvolvimento ovocitário, o tipo de desova e a fecundidade. O rio Grande foi amostrado mensalmente de janeiro a dezembro de 2004. A freqüência numérica dos estádios de maturidade e o método volumétrico foram utilizados para a determinação do período reprodutivo e da fecundidade, respectivamente. A reprodução de Oligosarcus hepsetus foi caracterizada por ter período longo, fecundidade relativamente baixa, comprimento de primeira maturação gonadal precoce e desova parcelada.
\end{abstract}

Palavras-chave: Oligosarcus hepsetus, reprodução, rio Grande, peixes neotropicais.

\section{Introduction}

One of the most important links in the life cycle of fish and in their populational dynamics is reproduction (Braga, 2001). Teleosteans achieved success in distinct environments due to various reproductive strategies that enable them to produce the maximum number of juveniles that survive to maturity under the conditions imposed by their environments (Lowe Mc-Connell, 1999). The general reproduction pattern exhibited by a species or population characterizes the strategies, while reproductive tactics are the variable characteristics within that pattern, which are evoked in response to environmental fluctuations. The length of the first gonadal maturation, the sex ratio, periods and type of spawning, oocyte development and fecundity are examples of the variable characteristics of reproductive strategy to each species (Vazzoler, 1996). Knowledge of these tactics and strate- gies is an indispensable element in guiding the management, handling and preservation of ichthyofauna in face of the impacts caused by anthropic actions such as fishing, pollution, the elimination of spawning and breeding areas through damming of water courses and destruction of marginal vegetation (Vazzoler and Menezes, 1992).

According to Vazzoler (1996), most Neotropical species display periodicity in their reproductive process, beginning their gonadal development during a period prior to reproduction and completing their gonadal maturation at such time as the environmental conditions are optimal for fecundation and for the development of their offspring, which is associated with the availability of food for their larvae (Bagenal, 1971).

The thin dogfish Oligosarcus hepsetus (Cuvier, 1829) is a small to medium-sized carnivore inhabiting mainly 
shallow densely vegetated microhabitats in small tributaries or in the shallows of major rivers (Araújo et al., 2005). This species is distributed in lagoons and rivers in the coastal region of southeastern Brazil between Santa Catarina and Rio de Janeiro (Menezes, 1987). It is important to determine the parameters of reproduction of carnivorous fishes because of the ecological characteristics of stabilization of the ecosystem, since they act in controlling the abundance of prey species (Nikolskii, 1963; Popova, 1978).

In Characiforms, the most generalized sexual dimorphism is the larger size of the females, possible related to a strategy linked with reproduction, for their fecundity increases with the length (Agostinho and Julio Jr., 1999).

The aim of this study was to characterize the reproduction of Oligosarcus hepsetus in the Grande river (Santa Virginia Unit - Serra do Mar State Park) based on the reproductive period, length of first gonadal maturation for both sexes, sexual proportion, oocyte development, type of spawn and fecundity.

\section{Material and Methods}

The collection site was the Grande river (Paraíba do Sul river basin) within of the Santa Virginia Unit of the Serra do Mar State Park. This State Park covers 16,000 ha in the municipalities of São Luiz do Paraitinga, Natividade da Serra, Cunha and Ubatuba, located at coordinates $23^{\circ} 24^{\prime}-23^{\circ} 17^{\prime} \mathrm{S}$ and $45^{\circ} 03^{\prime} \mathrm{W}$.

A total of 12 samples were made monthly from January to December 2004. At each sample point, individuals were collected using gill nets with mesh sizes of $1.5 ; 2.0 ; 2.5 ; 3.0 ; 3.5$, and 4.0 centimeters (measured between adjacent knots), with 10 meters long and $1.5 \mathrm{~m}$ high, totalizing 60 meters. In addition to the nets, sieves, and traps were also used.

Afterwards, specimens were kept in plastic containers containing $10 \%$ formalin. Each container received a label describing date and sample site.

Data of total weight $\left(\mathrm{W}_{\mathrm{t}}\right)$ in grams, total length $\left(\mathrm{L}_{\mathrm{t}}\right)$ in centimeters, sex, and gonad maturation stage were taken for each individual captured. The maturation stage of each specimen was determined macroscopically, considering coloration, transparency, superficial vascularization, and, for ovaries, the visualization and appearance of the oocytes. In agreement to a previously established scale, four different maturation stages were considered: A: immature, B: in maturation, $\mathrm{C}$ : mature, and D: spent. The reproductive period was analyzed according to the seasonal variation of the frequencies of the different maturation stages during the collecting periods. According to Vazzoler (1996), the $\mathrm{L}_{50}$ is the mean length of the first gonad maturation at which $50 \%$ of the individuals are adult, in other words, individuals that have begun the reproductive cycle. The length at which all individuals are apt for reproduction is represented by $\mathrm{L}_{100}$.

The i $\times 2$ type contingency table (where $\mathrm{i}>2$ ) was used for the sex-ratio analyses and the G-test was employed to ascertain the stages of maturity (A, B, C and D) (Vanzolini, 1993).
The gonadosomatic index (GI) was determined by the ratio between the weight of the gonad and the body weight of each specimen, multiplied by 100 (Vazzoler, 1996). The means of these relationships were determined in each stage of maturity for males and females.

For the study of fecundity, ovaries in stage $\mathrm{C}$ were extracted from the visceral cavity and weighted, then, their membranes were sectioned longitudinally throughout and immersed in modified Gilson solution. The vials containing the oocytes and the Gilson solution were periodically shaken and, after total disassociation, the oocytes were washed several times in $70 \%$ alcohol and kept in this solution. The fecundity was estimated according to the volumetric method (Vazzoler, 1996). The individual fecundity was estimated considering N' $=\mathrm{Sn} / \mathrm{s}$, where $\mathrm{S}$ is the volume of alcohol used to homogenize the mass of oocytes, $\mathrm{n}$ is the total number of oocytes counted in a sample of s volume obtained through a Stempel pipette. In this way we estimated the total number of oocytes, N', contained in the pair of disassociated ovaries. Since the individual fecundity is the number of mature oocytes and not the total number of oocytes contained in the ovaries, the formula $\mathrm{N}=\mathrm{N}$ 'P/100 was used to estimate the individual fecundity, where $\mathrm{P}$ is the percentage of oocytes in the ovaries with the diameter necessary for the oocytes to initiate the maturation process, in relation to the total number of oocytes (N'). The relative fecundity in length (RFL) and the relative fecundity in weight (RFW) was also estimated for Oligosarcus hepsetus.

\section{Results}

One hundred and eighteen specimens of Oligosarcus hepsetus were collected in the classes with total lengths of 3.1 to $23 \mathrm{~cm}$. Immature specimens were frequent in the classes with total lengths of 3.1 to $15 \mathrm{~cm}$, with males frequently ranging from 9.1 to $21 \mathrm{~cm}$ and females from 9.1 to $23 \mathrm{~cm}$ (Figure 1). An analysis of the Kolmogorov-Smirnov test (Vanzolini, 1993) applied to the frequency distributions of total lengths for males and females revealed a difference between these distributions $\left(\chi^{2}<0.05\right)$.

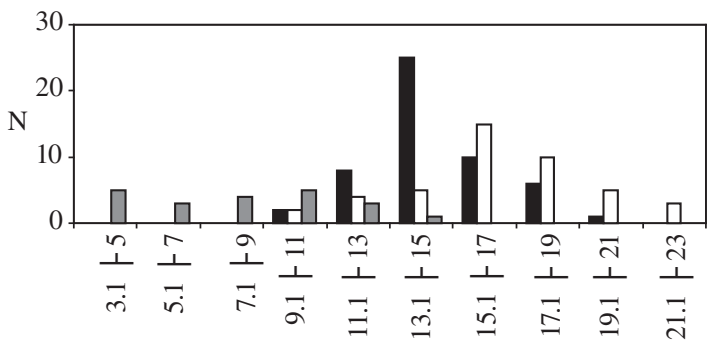

Length classes $(\mathrm{cm})$

- Males ¿Females ¿Immatures

Figure 1. Length distribution of Oligosarcus hepsetus for males, females, and immatures. 
The numerical frequency distribution of the sexes in each sampling indicated that immatures were frequent in every season of the year, with a greater number in the end of autumn and winter. There was no difference between females and males $\left(\chi^{2}>0.05\right)$ in their monthly and seasonal distributions (Figure 2).

The stages of maturity analyzed for males and females indicated seasonal differences $\left(\chi^{2}<0.05\right)$, with mature individuals more frequent from the end of winter to the beginning of autumn ( 8 months) and stage D (spent) individuals from the end of spring to summer (3 months) (Figure 3).

The $\mathrm{L}_{50}$ and $\mathrm{L}_{100}$ of Oligosarcus hepsetus were about 11.2 and $11.6 \mathrm{~cm}\left(\mathrm{~L}_{50}\right)$, for males as for females, respectively, and $16 \mathrm{~cm}\left(\mathrm{~L}_{100}\right)$ for both sexes, although females tended to mature at a length greater than that of males (Figure 4).

Table 1 shows the mean and standard deviations of the gonadosomatic index (GI) for male and female Oligosarcus hepsetus in the stages of gonadal maturity. The highest GI values were displayed by mature males and females, while stage D (spent) showed a high GI value in females.

The total number of oocytes (N') of the 22 pairs of ovaries analyzed from Oligosarcus hepsetus varied from 31,800 to 241,100 oocytes, with a mean of 79,404 (se $=10,619)$ oocytes. This number does not correspond

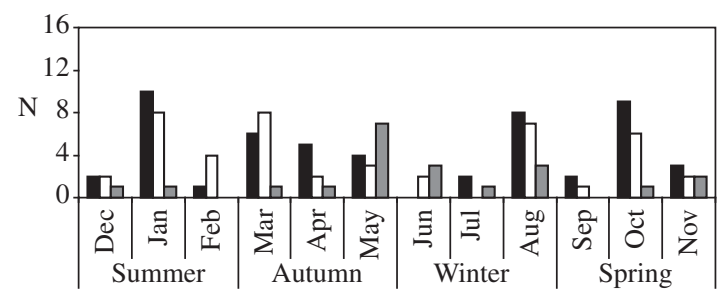

Samples

-Males „Females „Immatures

Figure 2. Numerical distribution of Oligosarcus hepsetus by sex, in each period of sample.

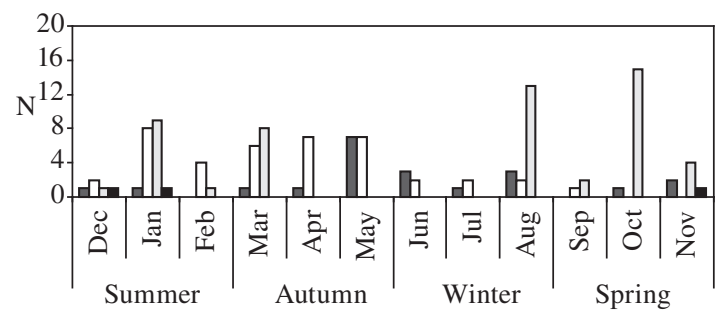

Samples

$$
\square \mathrm{A} \quad \mathrm{B} \quad \square \mathrm{C} \quad \mathrm{D}
$$

Figure 3. Numerical distribution of Oligosarcus hepsetus in the stages of gonadal maturity (A: immature, B: in maturation, C: mature, and D: spent) in each period of sample. to the fecundity, because it includes oocytes in the stock lot, in maturation, and mature oocytes. The fecundity $(\mathrm{N})$ varied from 697 to 47,736 oocytes, with a mean of 7,699 (se $=2,210$ ) oocytes. The mean RFL (relative fecundity in length) was 43 (se = 11) oocytes $/ \mathrm{mm}$, and the mean RFW (relative fecundity in weight) was 161 (se = 36) oocytes/g (Table 2).

The frequency of occurrence by size (diameter) class of oocytes indicated that parceled spawning was occurring. The oocytes matured at a size of $489.6 \mu \mathrm{m}$, reaching their maximum at $1,224 \mu \mathrm{m}$. The stock lot included oocytes from $61.2 \mu \mathrm{m}$ to $428.4 \mu \mathrm{m}$ (Figure 5).

\section{Discussion}

The specimens of Oligosarcus hepsetus in stage D occurred from the end of spring to summer, but the immatures occurred in every season of the year (except in February and September), thus evidencing a long reproductive period. Mature females and males can reproduce in different periods throughout the seasons, as in Oligosarcus jenynsii (Hartz et al., 1997). However, the reproductive period of Oligosarcus argenteus (Günther, 1864) and Oligosarcus longirostris Menezes and Géry, 1983 was found to occur only in summer (Neves et al., 1995; Gealh and Hahn, 1998). The long period of reproduction of Oligosarcus hepsetus was also characteristic of Oligosarcus jenynsii, which presented it from summer to spring in Argentina (Vazzoler and Menezes, 1992), from winter to summer in the Caconde and Fortaleza lagoons (RS) (Hartz et al., 1996; 1997; Nunes et al., 2004), and from winter to spring in the Custódias lagoon (RS) (Fialho et al., 1998). Prolonged reproductive periods occur in relatively stable environments

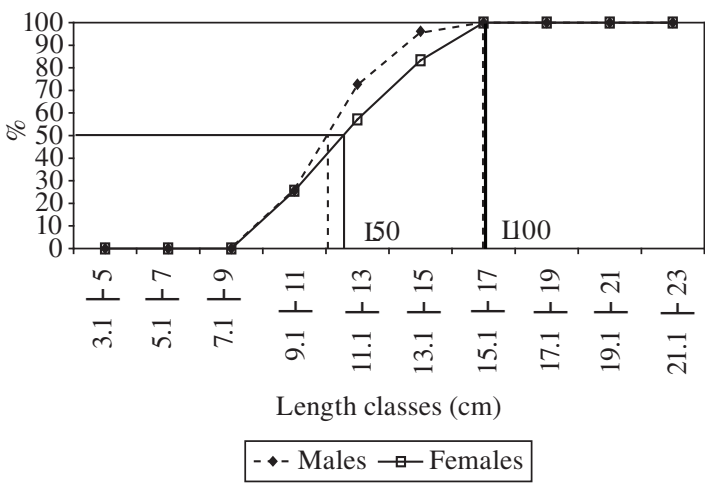

Figure 4. $\mathrm{L}_{50}$ and $\mathrm{L}_{100}$ of Oligosarcus hepsetus for males and females.

Table 1. Mean values and standard deviation of the gonadosomatic index (GI) for males and females of Oligosarcus hepsetus in each stage of maturity (B, C, and D) in Grande river.

\begin{tabular}{lrrrccc}
\hline & $\mathbf{N}$ & $\mathbf{B}$ & $\mathbf{N}$ & $\mathbf{C}$ & $\mathbf{N}$ & $\mathbf{D}$ \\
\hline Males & 19 & $0.7 \pm 0.35$ & 33 & $1.52 \pm 0.41$ & - & - \\
Females & 22 & $1.33 \pm 0.68$ & 20 & $4.8 \pm 1.88$ & 3 & $3 \pm 0.93$ \\
\hline
\end{tabular}



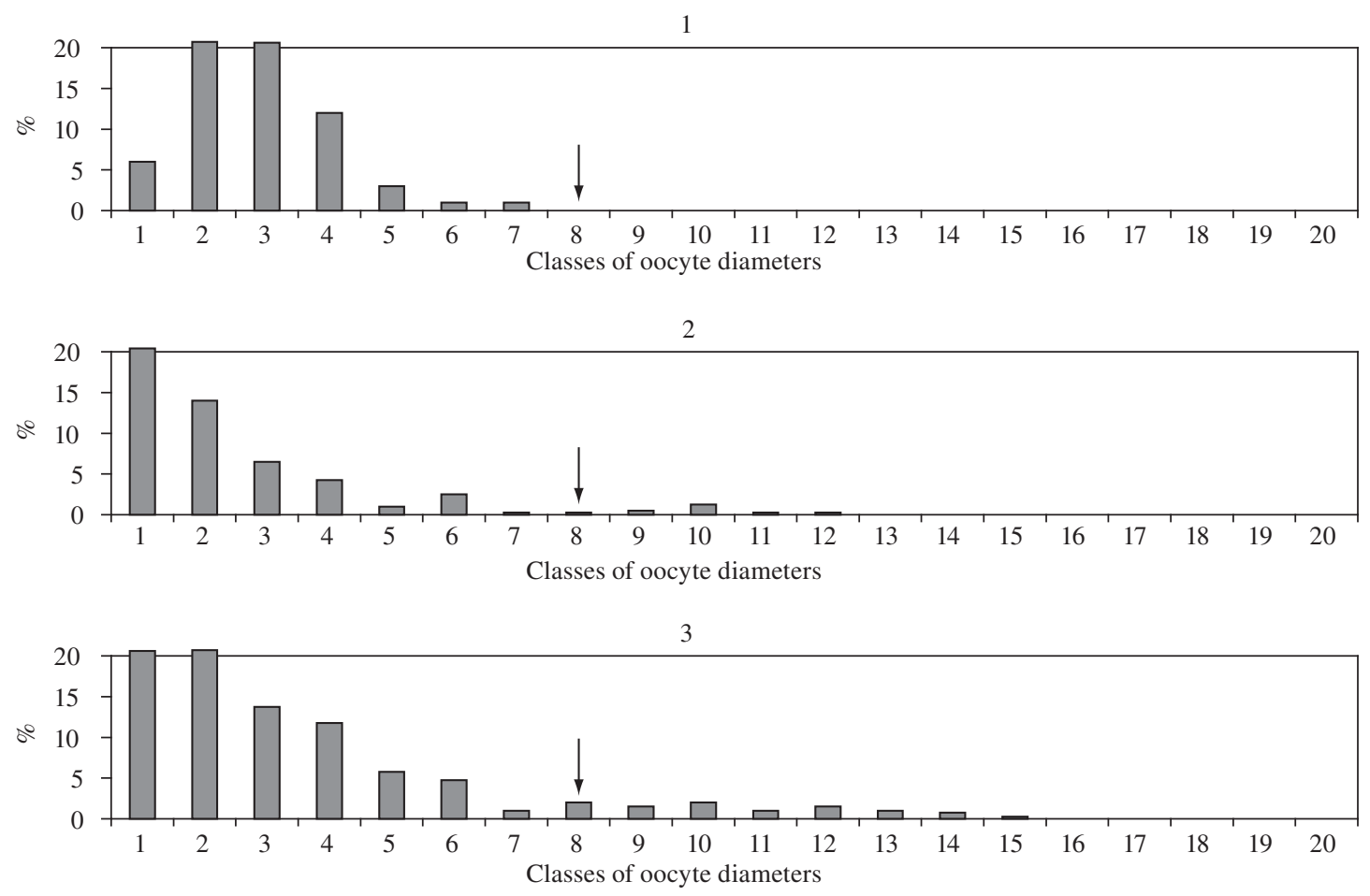

4

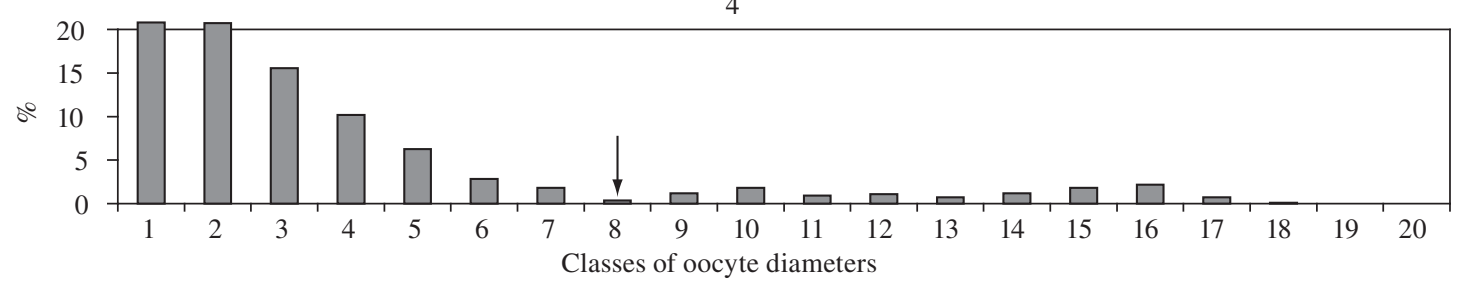

5

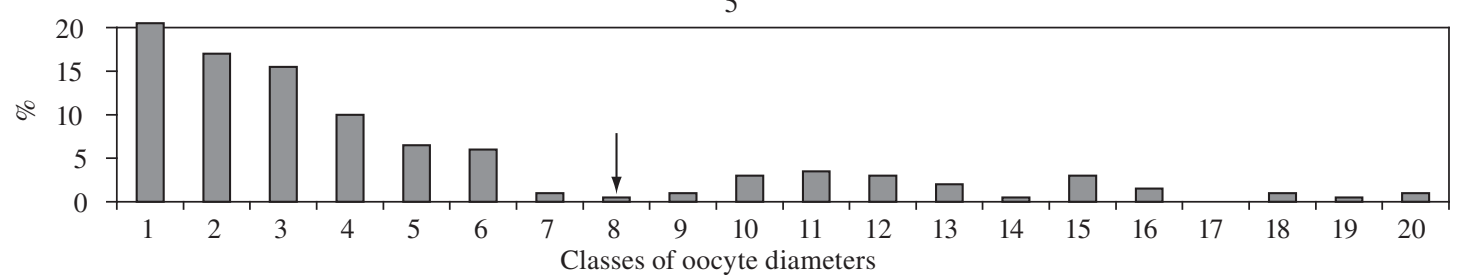

Figure 5. Frequency (in percentage) of the diametrical classes of oocytes, in d.o.m. (division of ocular micrometer) equivalent to 61,2 micrometer, of Oligosarcus hepsetus. Arrows indicate the size above which the oocytes become mature.

(Kramer, 1978). In the Santa Virgínia Unit is practically devoid of a dry season and the climatic conditions vary little due to its proximity to the ocean (Tonhasca Jr., 2005). Otherwise, reproductive seasonality is controlled by the availability of foods, by interspecies competition, and by breeding sites. This seasonality is either a mechanism for reproductive isolation or has no relationship to local conditions, but signifies the evolution of reproductive specializations that only occur under special conditions (Kramer, 1978). The reproductive period of piscivorous fish species precedes that of the remaining species, which have different feeding habits, probably so that their larvae are already more developed, giving them greater possibilities to prey on the other species when they hatch (Vazzoler, 1996). Precocious spawning ensures food for juveniles, but can increase the mortality of eggs and larvae due to low temperatures (Fialho et al., 1998).

The $\mathrm{L}_{50}$ of the males was lower than that of females, although the $\mathrm{L}_{100}$ was the same for both sexes. For Oligosarcus jenynsii, the values of first gonadal maturation $\left(\mathrm{L}_{50}\right)$ were very close to those of $O$. hepsetus, but the lengths at which all the individuals are able to reproduce $\left(\mathrm{L}_{100}\right)$ were different, with females reaching longer lengths than males (Hartz et al., 1997). The $\mathrm{L}_{50}$ and $\mathrm{L}_{100}$ values are adaptive to the environmental conditions of resource availability and species abundance (Vazzoler, 1996). 
Table 2. Total length $\left(\mathrm{L}_{\mathrm{t}}\right)$, total weight $\left(\mathrm{W}_{\mathrm{t}}\right)$, total number of oocytes $\left(\mathrm{N}^{\prime}\right)$, number of developing and mature oocytes $(\mathrm{N})$, relative fecundity in length (RFL), and relative fecundity in weight (RFW) of the individuals of Oligosarcus hepsetus from which the ovaries were analyzed.

\begin{tabular}{ccrrrr}
\hline $\mathbf{L}_{\mathbf{t}}(\mathbf{m m})$ & $\mathbf{W}_{\mathbf{t}}(\mathbf{g})$ & $\mathbf{N}$ & $\mathbf{N}$ & $\mathbf{R F L}$ & $\mathbf{R F W}$ \\
\hline 171 & 44.66 & 183,100 & 5,493 & 32.1 & 123 \\
202 & 76.57 & 241,100 & 4,822 & 23.9 & 63 \\
168 & 44.48 & 57,800 & 2,312 & 13.8 & 52 \\
165 & 38.57 & 55,300 & 3,871 & 23.5 & 100.4 \\
166 & 38.96 & 47,600 & 1,428 & 8.6 & 36.7 \\
161 & 27.78 & 92,000 & 1,840 & 11.4 & 66.2 \\
158 & 54.62 & 108,700 & 11,957 & 75.7 & 345.4 \\
128 & 27.49 & 69,700 & 697 & 5.4 & 25.4 \\
162 & 33.24 & 85,100 & 14,467 & 89.3 & 435.2 \\
169 & 40.69 & 38,900 & 3,112 & 18.4 & 76.5 \\
181 & 47.70 & 38,900 & 0 & 0 & 0 \\
141 & 24.73 & 39,100 & 5,474 & 38.8 & 221.4 \\
174 & 48.73 & 67,800 & 10,170 & 58.4 & 208.7 \\
204 & 79.82 & 64,200 & 3,210 & 15.7 & 40.2 \\
212 & 81.18 & 81,400 & 8,954 & 42.2 & 110.3 \\
205 & 84.36 & 62,100 & 9,936 & 48.5 & 117.8 \\
201 & 77.18 & 132,600 & 47,736 & 237.5 & 618.5 \\
143 & 24.39 & 55,000 & 7,700 & 53.8 & 315.7 \\
220 & 82.07 & 61,200 & 1,224 & 5.6 & 14.9 \\
175 & 45.08 & 73,200 & 21,228 & 121.3 & 470.9 \\
164 & 38.71 & 60,300 & 1,206 & 7.4 & 31.2 \\
154 & 30.85 & 31,800 & 2,544 & 16.5 & 82.5 \\
\hline
\end{tabular}

The gonadosomatic index (GI) in the stages of gonadal maturity were higher than those of the Oligosarcus hepsetus females and males in the oligotrophic reservoir of Lajes (RJ) (Santos et al., 2005; Santos et al., 2006) but similar to those found for Oligosarcus jenynsii in the Custódias lagoon (Fialho et al., 1998). According to Santos et al. (2006), these differences may be explained by the impacts of damming (Lajes reservoir), with the resulting scarcity of food and negative effects on reproduction. On the other hand, in the Custódias lagoon and the Grande river, the conditions of these natural systems favor high gonadosomatic index due to the wide availability of food and the environmental stability. The GI of females in stage D (spent) was characteristic of species that spawn in parcels (Fialho et al., 1998) and that still keep oocyte lots in their ovaries in maturation for subsequent spawning.

The fecundity of Oligosarcus hepsetus was relatively low compared with migratory fish species. This fecundity matches that of nonmigratory species with external fecundation and without parental care, which usually have intermediary fecundity (Vazzoler and Menezes, 1992; Vazzoler, 1996). The average fecundities of 17,684 and 20,727 oocytes of Oligosarcus jenynsii in the Caconde lagoon and the upper Uruguay river (RS) (Hartz et al., 1997; Hermes-Silva et al., 2004) were higher than those of Oligosarcus hepsetus, but the minimum and maximum fecundity values presented by the former were similar to those of Oligosarcus hepsetus. The sampled specimens of Oligosarcus jenynsii were larger than those of Oligosarcus hepsetus, which may explain the differences in the average fecundities of the species in these two sites. In addition, the mean fecundity of 9,694 oocytes presented by smaller specimens of Oligosarcus jenynsii in the Custódias lagoon (Fialho et al., 1998) was similar to that of Oligosarcus hepsetus.

Mature oocyte size $(1,300 \mu \mathrm{m})$ and relative fecundity in weight (182 oocytes per gram) of Oligosarcus jenynsii (Hermes-Silva et al., 2004) were similar to those of Oligosarcus hepsetus in the Grande river.

In species that do not make extensive reproductive migrations and have lower fecundities than migratory species, adaptations take place to compensate for the high mortality in the early phases of life, which may include multiple or parceled spawning with a longer reproductive period (Vazzoler and Menezes, 1992). Oligosarcus hepsetus showed fractional spawning, as did the same species in the Lajes reservoir (Santos et al., 2005), as well as Oligosarcus jenynsii (Hartz et al., 1997; HermesSilva et al., 2004) and Oligosarcus robustus (Nunes et al., 2004). This type of spawning is characterized by the synchronic development of oocyte lots in progressive stages of maturation, which will be eliminated along the reproductive period (Vazzoler, 1996), and is a frequent strategy of species living in stable (Mazzoni and 
Iglesias-Rios, 2002) and restricted conditions for the survival of eggs and larvae (Nikolskii, 1969; Bagenal, 1971; Jepsen et al., 1999).

The characteristics of small size, great colonization ability, precocious maturation, continuous parceled reproduction and small number of offspring of Oligosarcus hepsetus fit the opportunistic strategy proposed by Winemiller (1989).

Acknowledgments - The authors wish to thank FAPESP (proc. 03/05696-1) for financial support, Cotec (proc. 40.673/03), IBAMA (aut. 055/2003), and to Mr. J. P. Villani (Director of the Santa Virgínia Unit) for making it possible to carry out this research.

\section{References}

AGOSTINHO, AA. and JÚLIO-JR., HF., 1999. Peixes da bacia do alto rio Paraná. In Estudos ecológicos de comunidades de peixes tropicais. LOWE-McCONNELL, RH. Editora da Universidade de São Paulo, São Paulo, p. 374-400.

ARAÚJO, FG., ANDRADE, CC., SANTOS, RN., SANTOS AFGN. and SANTOS, LN., 2005. Spatial and seasonal changes in the diet of Oligosarcus hepsetus (Characiformes, Characidae) in a brazilian reservoir. Rev. Bras. Zool., vol. 65, no. 1, p. 1-8.

BAGENAL, TB., 1971. The interrelation of the size of fish eggs, the date of spawning and the production cycle. J. Fish Biol., vol. 3 , no. 2, p. 207-219.

BRAGA, FMS., 2001. Reprodução de peixes (Osteichthyes) em afluentes do reservatório de Volta Grande, rio Grande, sudeste do Brasil. Iheringia, vol. 91, no. 1, p. 67-74.

FIALHO, CB., SCHIFINO, LC. and VERANI, JR., 1998. Biologia reprodutiva de Oligosarcus jenynsii (Günther) (Characiformes, Characidae) da lagoa das Custódias, Tramandaí, Rio Grande do Sul, Brasil. Rev. Bras. Zool., vol. 15, no. 3, p. 775-782.

GEALH, AM. and HAHN, NS., 1998. Alimentação de Oligosarcus longirostris MENEZES and GÉRY (Osteichthyes, Acestrorhynchinae) do reservatório de Salto Segredo, Paraná, Brasil. Rev. Bras. Zool., vol. 15, no. 4, p. 985-993.

HARTZ, SM., MARTINS, A. and BARBIERI, G., 1996. Dinâmica da alimentação e dieta de Oligosarcus jenynsii (Günther, 1864) na lagoa Caconde, Rio Grande do Sul, Brasil (TEleOSTEI, CHARACIDAE). Bol. Inst. Pesca, São Paulo, vol. 23, p. 21-29.

HARTZ, SM., VILELLA, FS. and BARBIERI, G., 1997. Reproduction dynamics of Oligosarcus jenynsii (Characiformes, Characidae) in lake Caconde, Rio Grande do Sul, Brazil. Rev. Bras. Biol., vol. 57, no. 2, p. 295-303.

HERMES-SILVA, S., MEURER, S. and ZANIBONI-FILHO, E., 2004. Biologia alimentar e reprodutiva do peixe-cachorro (Oligosarcus jenynsii Günther, 1864) na região do alto rio Uruguai - Brasil. Acta Scientiarum, Maringá, vol. 26, no. 2, p. $175-179$.

JEPSEN, DB., WINEMILLER, KO., TAPHORN, DC. and RODRIGUES OLARTE, D., 1999. Age structure and growth of peacock cichlids from rivers and reservoirs of Venezuela. J. Fish Biol., vol. 55, no. 2, p. 433-450.

KRAMER, DL., 1978. Reproductive seasonality in the fishes of a tropical stream. Ecology, vol. 59, no. 5, p. 976-985.
LOWE-MCCONNELL, RH., 1999. Estudos ecológicos de comunidades de peixes tropicais. Tradução de VAZZOLER, AEAM., AGOSTINHO, AA. and CUNNIGHAN, P. São Paulo. Ed. da Universidade de São Paulo. Título original: Ecological studies in tropical fish communities, $535 \mathrm{p}$.

MAZZONI, R. and IGLESIAS-RIOS, R., 2002. Distribution pattern of two fish species in a coastal stream in Southeast Brazil. Braz. J. Biol., vol. 62, no. 1, p. 171-178.

MENEZES, NA., 1987. Três espécies novas de Oligosarcus GÜNTHER, 1864 e redefinição taxonômica das demais espécies do gênero (Osteichthyes, Teleostei, Characidae). Bolm. Zool., vol. 11, p. 1-39.

NEVES, CA., ANDRADE, DR., MATTA, SLP., VIDAL, MV. and SANTOS, AA., 1995. Cytochemical analysis of polysaccharides from the cortical alveoli of the oocytes of the lambari-bocarra (Oligosarcus argenteus Gunther, 1864) (Pisces, Characidae). Rev. Bras. Biol., vol. 55, no. 4, p. 693-696.

NIKOLSKII, GV., 1963. The ecology of fishes. London: Academic Press, 352 p.

-, 1969. Theory of fish population dynamics. Oliver \& Boyd. Edinburgh. 321 p.

NUNES, DM., PELLANDA, M. and HARTZ, SM., 2004. Dinâmica reprodutiva de Oligosarcus jenynsii e Oligosarcus robustus (Characiformes, Characidae) na lagoa Fortaleza, Rio Grande do Sul, Brasil. Iheringia, Porto Alegre, vol. 94, no. 1, 5-11.

POPOVA, OA., 1978. The role of predaceous fish in ecosystems. Ed. GERKING, SD. Blackwell Scientific, Oxford, p. 215-249.

SANTOS, RN., ANDRADE, CC., SANTOS, AFGN., SANTOS, LN. and ARAÚJO, FG., 2005. Hystological analysis of ovarian development of the Characiform Oligosarcus hepsetus (Cuvier, 1829) in a brazilian reservoir. Braz. J. Biol., vol. 65, no. 1, p. $169-177$.

SANTOS, RN., ANDRADE, CC., SANTOS, LN., SANTOS, AFGN. and ARAÚJO, FG., 2006. Testicular maturation of Oligosarcus hepsetus (Cuvier) (Actinopterygii, Characidae) in a brazilian tropical reservoir. Braz. J. Biol., vol. 66, no. 1a, p. $143-150$.

TONHASCA JR., A., 2005. Ecologia e história natural da Mata Atlântica. Editora Interciência, Rio de Janeiro, 197 p.

VANZOLINI, PE., 1993. Métodos estatísticos elementares em sistemática zoológica. Ed. HUCITEC., São Paulo, 130 p.

VAZZOLER, AEAM., 1996, Biologia da reprodução de peixes teleósteos: Teoria e Prática. Maringá-PR, Nupelia, 169 p.

VAZZOLER, AEAM. and MENEZES, NA., 1992. Síntese de conhecimentos sobre o comportamento reprodutivo dos Characiformes da América do Sul (Teleostei, Ostariophysi). Rev. Brasil. Biol., vol. 52, no. 4, p. 627-640.

WINEMILLER, KO., 1989. Patterns of variation in life history among South American fishes in seasonal environments. Oecologia, vol. 81, no. 2, p. 225-241. 